\title{
Groundwater Arsenic Contamination in Bihar: Causes, Issues and Challenges
}

\author{
Barun Kumar Thakur* and Vijaya Gupta**
}

\begin{abstract}
Around forty percent of the district of Bihar is having arsenic in its groundwater. The causes of arsenic contamination are mostly through geogenic channel. Excess use of arsenic in drinking water over prolonged period leads to primary, secondary and tertiary health impacts. The agricultural activity is getting hampered due to decline in soil fertility, productivity, and, nuisance of food chain problem. Social problems like depression, suicidal tendency and social ignorance are common, and, therefore, hinder the social and economic activity to the affected person. The majority of the population residing in the arsenic prone belt are from low income and are not aware about the problems of the arsenic menace. The challenges are on the mitigation (at macro) and adaptation (micro and macro) activity. Therefore both short and long term mitigation strategy is needed.
\end{abstract}

Keywords: Groundwater, Arsenic contamination, Socio-economic problems, mitigation strategy, Bihar.

\subsection{Introduction}

Bihar along with few other states of India is facing a severe problem due to arsenic menace in groundwater. Groundwater is the main source of drinking water and it constitutes more than 80 per cent of drinking source in rural Bihar. The other sources of drinking water are from surface water, dug well, pond and from natural sources (lakes, rivers etc.) and protected dug well. The groundwater sources were considered safe for drinking water but over the past few years, they have reported contamination and pollution problems in its root due to rapid urbanisation, increase in population, industrialisation and excess and uncontrolled extraction of groundwater for irrigation and other purposes.

*Research Scholar, National Institute of Industrial Engineering (NITIE), Mumbai.

**Professor, National Institute of Industrial Engineering (NITIE), Mumbai. 
Around 40 percent districts of Bihar have reported arsenic in its groundwater. This comprises more than 67 blocks from 15 districts and covering more than 1600 habitations across the state where arsenic contamination in groundwater exceeds the Bureau of Indian Standard(BIS) limits for safe drinking water of 50 parts per billion (ppb) and more. If we consider the WHO limits of $10 \mathrm{ppb}$, the coverage area will be much more and the population which is facing the danger of arsenic hazard will be more than the BIS standard limit. It is estimated that more than 13.85 million people could be under the threat of contamination level above $10 \mathrm{ppb} / 1$, out of which more than 6.96 million people could be above $50 \mathrm{ppb} / \mathrm{l}$, against the total population of these area is around 50 million (Ministry of Water Resources, 2010). The actual problem of arsenic menace among the population will be more than the estimate due to increase in affected area after every new survey.

Arsenic is a shiny metalloid that dissolves in water. It is a natural mineral, present in the soil and aquifers, and the concentrations above the safe level in drinking water may cause significant health risks. Most arsenic enters water supplies either from natural deposits in the earth or from industrial and agricultural pollution. Arsenic is a natural element of the earth's crust. Although surface water are mostly considered safe for drinking water but groundwater sources are arsenic contaminated in the range of $40-$ 140 feet.

Access to safe water supply is one of the most important factors of health and socio-economic development (Cvjetanovic, 1986). More than 150 million people are affected worldwide by arsenic contamination in 70 countries, out of which 50 million people in Bangladesh and 30 million people in India are at risk (Ravenscroft et al., 2008, 2009). Arsenic is toxic in nature and the excess quantity of its use in drinking water leads to several health hazards. Drinking arsenic contaminated water over a long period results in various health effects including skin problems such as colour changes on the skin, and hard patches on the palms and soles of the feet (WHO, 2010). It also leads to skin cancer, cancer of the bladders, kidney and lung, and diseases of the blood vessels of the legs and feet, and also possibly diabetes, high blood pressure and reproductive disorders (WHO. 2010)

Given the background, this paper attempts to understand the issues and challenges posed by arsenic groundwater contamination problems and its menace of the affected population in Bihar. Followed by brief introduction and background problem, the paper is organised in following way. The second section is on water pollution and arsenic scenario. In this section, water pollution and arsenic scenario in Bihar is given in details. The third section deals with issues and challenges faced by arsenic in drinking 
water and possible solutions for the emerging challenges. The fourth section comprises concluding remarks.

\subsection{Water pollution and arsenic scenario}

Air and water pollution are major environmental problems that currently exist in India along with depletion of nonrenewable resources and degradation of renewable resources (Sankar, 2000). While resources are for economic good, pollutants are the degrader of resources and hence economically undesirable. Pollutants are the reverse of the resources (Dasgupta, 2010) and pollution is thus the reverse of conservation (Dasgupta, 1993 and 2007). Pollution can be thought of as a pure public bad and hence pollution reduction as a public good (Baliga and Maskin, 2005). Pollution is treated as negative externalities in economics literature (Pigou, 1920, Sankar, 2005). When certain actions of producers or consumers have unintended effects on other producers or consumers externality arises. Externality is of two kinds positive and negative. Externalities may be global public bads (emissions of greenhouse gases, climate change, depletion of ozone layer, loss of bio-diversity and extinction of endangered species and other are some of the examples of global public bads) which have global effect and local public bads (problem of groundwater or surface water in a region, land degradation, air and vehicular pollutions and others are some of the examples of the local public bads) which have local or regional effect. Climate change problem worsen the availability of water in the country as it threatens the water cycle. As the population increases, the demand for agriculture also grows and the demand of water thus increases. Projected water demand in India by different users is shown in Table 1.

\subsection{Water pollution}

Water pollution is a major concern in India and particular in Bihar. With around 17 percent of the world's population but only 4 percent of its usable freshwater, India has a scarcity of water. World oceans cover about 3/4th of earth's surface. But fresh water constitutes small proportions. About 2.7 percent of the total water available on the earth is fresh water, of which about 75.2 percent lies frozen in Polar Regions and another 22.6 percent is present as groundwater (Ministry of Water Resources, 2007; UN, 2005). A small proportion of total fresh water ( 2 percent) is available in lakes, rivers, atmosphere moisture, soil and vegetation. Water resources of a country constitute one of its most significant economic assets and the different forms of water resource development differ for various uses, fluctuate from country to country depending on its climatic, physiographic, and socio-economic conditions and development (Jain, 1977). 
Table 1: Projected water demand in India (by different uses)

\begin{tabular}{|l|l|l|l|l|l|l|l|l|l|l|}
\hline \multirow{3}{*}{$\begin{array}{l}\text { S1 } \\
\text { No. }\end{array}$} & \multirow{8}{*}{ Sector } & $\begin{array}{l}\text { Standing Sub- } \\
\text { committee of Ministry } \\
\text { of Water Resources }\end{array}$ & \multicolumn{7}{|c|}{ NCIWRD } \\
\cline { 4 - 12 } & & 2010 & 2025 & 2050 & 2010 & 2025 & 2050 \\
\cline { 3 - 12 } & & & & & Low & High & Low & High & Low & High \\
\hline 1 & Irrigation & 688 & 910 & 1072 & 543 & 557 & 561 & 611 & 628 & 807 \\
\hline 2 & $\begin{array}{l}\text { Drinking } \\
\text { Water }\end{array}$ & 56 & 73 & 102 & 42 & 43 & 55 & 62 & 90 & 111 \\
\hline 3 & Industry & 12 & 23 & 63 & 37 & 37 & 67 & 67 & 81 & 81 \\
\hline 4 & Energy & 5 & 15 & 130 & 18 & 19 & 31 & 33 & 63 & 70 \\
\hline 5 & Other & 52 & 72 & 80 & 54 & 54 & 70 & 70 & 111 & 111 \\
\hline & Total & 813 & 1093 & 1447 & 694 & 710 & 784 & 843 & 973 & 1180 \\
\hline
\end{tabular}

Source: Ministry of Water Resources, 2010

India is rich in both surface water and groundwater resources. India has total annual replenishable groundwater resources of 433 billion cubic meters (BCM), net annual groundwater availability of $399 \mathrm{BCM}$, and annual ground water draft for irrigation, domestic and industry is around $233 \mathrm{BCM}$, and stage of groundwater development is around 58 percent. Annual precipitation (includes snowfall) in India is 4000 cubic kilometers while average annual availability of water resources is around 1869 cubic kilometers. Per capita water availability is 1820 cubic meters (Ministry of Water Resources, 2010). Estimated utilised water resources is 1122 cubic kilometers in which surface water resources share is 690 cubic kilometers and groundwater resource share is 431 cubic kilometers.

Bihar is rich in groundwater resources. In Bihar, annual replenishable groundwater resources, net annual groundwater availability and annual groundwater draft are 29, 27.42, and 10.77 BCM. The stage of groundwater development in Bihar is 39 percent and the annual rainfalls (in $\mathrm{mm}$ ) are 1232. The per capita water availability is decreasing in both Bihar and India. In 2001, per capita availability of water (in cu. m) was 1950 and 1816 for Bihar and India. It has further decline to 1545 and 1200 (in cu. M) in 2011. The decline in availability of groundwater is due to uncontrolled population growth, excess dependence on groundwater (85 percent), over extraction of groundwater for irrigation, uncontrolled deforestation. This leads to overall water quality problems. But water is becoming increasingly scarce over the years. Uncontrolled growth of population, expansion of irrigation channels and developmental activity are responsible 
for the decline in water availability problems. It also leads to problems in water quality which affects the health and other problems. The groundwater problems in Bihar have been summarised in Table 2.

\section{Table 2: Groundwater Pollution in Bihar}

\begin{tabular}{|c|c|c|c|}
\hline Contamination & $\begin{array}{l}\text { Permissible } \\
\text { Limit }\end{array}$ & $\begin{array}{l}\text { Health } \\
\text { Effects }\end{array}$ & Location and Status \\
\hline 1. Arsenic & $\begin{array}{l}10 \mathrm{ppb} \text { by WHO } \\
50 \mathrm{ppb} \text { by BIS } \\
>50 \mathrm{ppb} \text { leads } \\
\text { to health } \\
\text { problems }\end{array}$ & $\begin{array}{l}>50 \mathrm{ppb} \text { in } \\
\text { drinking } \\
\text { water is toxic } \\
\text { and } \\
\text { have human } \\
\text { health } \\
\text { hazard }\end{array}$ & $\begin{array}{l}15 \text { districts and } 57 \text { blocks of Bihar are } \\
\text { highly } \\
\text { affected by arsenic in their } \\
\text { groundwater. Arsenic is toxic in } \\
\text { nature and excess use of it in drinking } \\
\text { water for long run causes different } \\
\text { kind of cancer. It also hampers the } \\
\text { socio-economic conditions of the } \\
\text { affected persons. The highest } \\
\text { concentration of contamination was } \\
\text { found } 1810 \text { and } 1630 \text { ppb at Maner } \\
\text { and Shahpur block of Patna and } \\
\text { Bhoipur district. }\end{array}$ \\
\hline 2. Fluoride & $\begin{array}{l}\text { Upto } 1.5 \mathrm{mg} / \mathrm{l} \text { in } \\
\text { drinking water } \\
<1 \mathrm{mg} / \mathrm{l} \text { is } \\
\text { Beneficial }\end{array}$ & $\begin{array}{l}>1.5 \mathrm{mg} / \mathrm{l} \text { is } \\
\text { harmful } \\
\text { and resulted in } \\
\text { staining of } \\
\text { tooth } \\
\text { enamel }\end{array}$ & $\begin{array}{l}14 \text { blocks of } 9 \text { districts and highest } \\
\text { concentration was at Navinagar }(2.85 \\
\mathrm{mg} / \mathrm{l}) \text { of Jamui block. Higher level of } \\
\text { fluoride }(5-10 \mathrm{mg} / \mathrm{l}) \text { causes stiffness } \\
\text { of the back and difficulty in } \\
\text { performing natural movement. }\end{array}$ \\
\hline 3. Iron & $\begin{array}{l}\text { Upto } 1 \mathrm{mg} / \mathrm{l} \text { in } \\
\text { drinking water }\end{array}$ & $\begin{array}{l}>1.5 \mathrm{mg} / \mathrm{l} \text { is } \\
\text { harmful }\end{array}$ & $\begin{array}{l}\text { Iron is common water contaminant } \\
\text { found in Bihar. } 31 \text { blocks from } 20 \\
\text { districts is having Iron in } \\
\text { groundwater. The highest } \\
\text { concentration of Iron was found at } \\
\text { Jeradai }(14 \mathrm{mg} / \mathrm{l}) \text { of Mairwa block } \\
\text { from Siwan district. }\end{array}$ \\
\hline 4. Nitrate & $\begin{array}{l}\text { Upto } 45 \mathrm{mg} / \mathrm{l} \text { in } \\
\text { drinking water }\end{array}$ & $\begin{array}{l}>45 \mathrm{mg} / \mathrm{l} \text { in } \\
\text { drinking } \\
\text { water is } \\
\text { harmful for } \\
\text { infants }\end{array}$ & $\begin{array}{l}\text { It is difficult to identify natural and } \\
\text { man-made } \\
\text { sources of nitrogen in ground water. It } \\
\text { generally originates from non-point } \\
\text { sources and is the most common } \\
\text { contaminant of groundwater. } 15 \text { blocks } \\
\text { from } 9 \text { districts is having Iron in } \\
\text { Bihar. The highest concentration was } \\
\text { found at Mokama ( } 228 \mathrm{mg} / \mathrm{l}) \text { of } \\
\text { Fatuah block from Patna. }\end{array}$ \\
\hline
\end{tabular}




\subsection{Arsenic contamination: Causes and sources}

Arsenic is found in the natural environment in plenty in the earth's crust and in small magnitudes in rock, soil, water and air and is always present as compounds with oxygen, chlorine, sulphur, carbon and hydrogen on one hand, and with lead, gold and iron on the other (Ministry of Water Resources, 2010b). It can exist in both organic and inorganic form but inorganic arsenic is more toxic than organic arsenic. Inorganic arsenic compounds are known to be more human carcinogens. Arsenic in element form is insoluble in water and soluble in oxidized form. Countries including Argentina, Bangladesh, Chile, Ghana, Mexico, Mongolia, India, Taiwan, Vietnam, and United States are exposed to arsenic problems because the sources of arsenic are primarily natural rather than anthropogenic or geothermal. Inorganic arsenic of geological origin has been recognised as the main form of arsenic in groundwater.

Sparks (2005) suggested three source of arsenic in soil and aquatic ecosystem. It consists of biogenic, geogenic and anthropogenic sources of arsenic. By and large geogenic sources are responsible for arsenic contamination but anthropogenic activities also cause contamination. The anthropogenic sources of arsenic occur due to human activities. The main source of anthropogenic can be further classified in three categories viz. agricultural, industrial and others. Agricultural sources of arsenic can be from pesticides, herbicides, seed treatment, cattle deep and fertilizer mainly, while industrial sources are from timber treatment, tannery, electro plastic, and paints and chemicals. Other anthropogenic sources are from sewage and smelting.

\subsection{Arsenic scenario in Bihar}

Arsenic is a heavy metal and regarded as a toxic element. Excess of arsenic in drinking water over long run is considered as a human health hazard and leads to different diseases. In extreme cases it leads to an end of human life. Seven states of India have reported arsenic contamination in groundwater and it is increasing at increasing rate (Ministry of Environment and Forest, 2009). Out of reported seven states, Bihar and West Bengal have severe impact of the livelihoods of the stakeholders due to arsenic menace.

More than 70 countries are globally affected directly or indirectly with arsenic contamination in drinking water which affects more than 150 million people across the globe. Around middle of the 20th century, arsenic poisoning surfaced in those areas where people ingested arsenic contaminated water. The major affected countries from arsenic poisoning were Argentina, Chile, Mexico, Taiwan, and some part of the United States. In global arsenic scenario, 38 countries are affected more severely at present. At the last quarter of 20th century three Asian countries (Bangladesh, China, and India) 
came to lime light due to their suffering from groundwater arsenic contamination. The major source of arsenic contamination was contaminated hand tube-wells. As of 2010 September, 13 Asian countries were arsenic affected and the level of arsenic contamination in Asian countries was more severe than the rest of the world. Bangladesh is the worst affected country, as 60 of its total 64 districts have arsenic groundwater contamination above World Health Organization (WHO), 2001 guidelines of 10mg/l for safe drinking in water. In India, flood plains of all the states in Ganga and Brahmaputra rivers are arsenic affected.

The first case of arsenic in India was reported in 1976 from Chandigarh, where some patients were suffering from noncirrhotic portal hypertension (NCPH) and later it was found that the water used by patients who suffered from NCPH came from arsenic contaminated tube wells (Ministry of Water Resources, 2010b). In 1982 a patient from North - 24 Parganas district of West Bengal, reported skin lesions which were not like the usual skin diseases and later, similar problems were found in many patients from the same village suffered from such problems in soles of their feet, palms of their hands, ulcers in hands and bodies. It was found that the cause of theses was the excess availability of arsenic in tube wells in drinking water (Ministry of Water Resources, 2010a). Soon after the incident four districts of West Bengal (North 24 Parganas, South 24 Parganas, Nadia, and Murshidabad) were found on arsenic menace in ground water. In 1983, 33 villages of 4 districts were identified, having arsenic contamination. By the end of 2004, 3200 villages of 85 blocks from 9 districts were identified having arsenic contaminated water and by the end of 2008, more than 3417 villages of 111 blocks from 9 districts have reported arsenic contaminated groundwater (Ministry of Water Resources, 2010b).

As of 2009, out of 38 districts of Bihar, 57 blocks from 15 districts having total population more than 10 million have been reported to have arsenic groundwater contamination above $50 \mathrm{mg} / \mathrm{l}$ (Ministry of Water Resources, 2010a and 2010b, Ministry of Environment and Forest, 2009). Due to the excess arsenic contaminated drinking water, 18 babies were born blind in the Bhojpur district. The demographic survey done by many organisations mainly in Bihar and West Bengal estimated that more than 13.85 million people could be under the threat of contamination level above $10 \mathrm{mg} / \mathrm{l}$, in which more than 6.96 million people could be above $50 \mathrm{mg} / \mathrm{l}$, against the total population of those areas of the order of 50 million (Ministry of Water Resources, 2010b). Live-stock in large number has also been exposed to arsenic contaminated groundwater. In the arsenic affected areas, arsenic contaminated groundwater is also used for agricultural irrigation. This leads to the possibility of arsenic exposure through food chain not only in 
contaminated areas but also in areas with no contamination due to open market sale of food products.

Out of seven states, two states of India namely Bihar and West Bengal are worst affected by arsenic contamination in their groundwater. Altogether more than 40 percent of the people from Bihar and West Bengal are affected by arsenic contamination in groundwater which causes serious threats to the people of the state in health and other hazards which threats to the socio - economic status of the affected people. Table 3 presents the arsenic contamination problem in Bihar.

Table 3: Arsenic in Groundwater of Bihar (> $50 \mathrm{ppb} / \mathrm{l}$ )

\begin{tabular}{|l|l|l|l|l|l|l|}
\hline District & $\begin{array}{l}\text { Total } \\
\text { Block }\end{array}$ & $\begin{array}{l}\text { Total } \\
\text { Affected } \\
\text { Blocks }\end{array}$ & $\begin{array}{l}\text { Total } \\
\text { surveyed } \\
\text { Habitations }\end{array}$ & $\begin{array}{l}\text { Total } \\
\text { Affected } \\
\text { Habitations }\end{array}$ & $\begin{array}{l}\text { Maximum } \\
\text { concentration } \\
\text { in ppb }\end{array}$ & $\begin{array}{l}\text { Minimum } \\
\text { concentration } \\
\text { in ppb }\end{array}$ \\
\hline Begusarai & 18 & 4 & 174 & 84 & & \\
\hline Bhagalpur & 16 & 4 & 216 & 159 & & \\
\hline Bhojpur & 14 & 4 & 316 & 231 & 1630 & BDL \\
\hline Buxar & 11 & 4 & 512 & 385 & 1400 & BDL \\
\hline Darbhanga & 18 & 1 & 29 & 5 & 218 & BDL \\
\hline Katihar & 16 & 5 & 112 & 26 & & \\
\hline Khagaria & 7 & 4 & 376 & 246 & & \\
\hline Lakhisarai & 7 & 3 & 320 & 204 & & \\
\hline Munger & 9 & 4 & 178 & 118 & & BDL \\
\hline Patna & 23 & 4 & 218 & 65 & 1810 & BDL \\
\hline Samastipur & 20 & 4 & 248 & 154 & 626 & \\
\hline Saran & 20 & 4 & 74 & 37 & 374 & \\
\hline Vaishali & 16 & 5 & 173 & 76 & & \\
\hline Total & 195 & 50 & 2,946 & 1,590 & & \\
\hline
\end{tabular}

Source: Public Health Engineering Department, Govt. of Bihar (2012)

\subsection{Issues and Challenges}

Scarcity of safe drinking water in the rural areas of Bihar acquainted with social and economic issues. It also threats the environment as well as major health problems. Contamination in drinking water hinders the social and economic activity to the affected person. The evidence on the adverse impacts of water pollution in general and on human health in particular is well known. High concentration of contamination in drinking water - arsenic, fluoride, iron, nitrate and lead- contribute to both human mortality and 
morbidity. Prolonged exposure to water contamination could lead to different diseases. Epidemiological studies show that arsenic in drinking water cause cancer (Canter 1997, Chakraborty and Saha, 1987). Arsenic in drinking water over long run can cause the problems in the reproductive system, birth defects and harm the central and peripheral nervous system (Canter, 1997) and excess acquaintance of arsenic during pregnancy can adversely affect reproductive endpoints (Mukherjee, 2006). The dose-response relation between low arsenic concentrations in drinking water and arsenic-induced skin Keratosis and hyper pigmentation is well characterised (Haque et al., 2003). The arsenic related skin disease may be associated with increased risks of skin, bladder and lung cancer (NRC, 1999). Such health problems involved economic, social and environmental costs to the affected stakeholders. Arsenic in drinking water hinders the social as well as economic costs to the society in general and affected households in particular. Health problems caused by pollution have economic costs arising from the expenses incurred in treating the disease and loss of productivity (Bates, 1990, Ostro, 1994, Banerjee, 2001, Adhikari, 2012). Skin lesions poses an important public health concern in Bangladesh and West Bengal, India as advanced forms of Keratosis are painful and if untreated can lead to social isolation among the affected villages (Haque et al., 2003, Haque and Khan, 2011).

Most of the arsenic studies are epidemiological studies. In epidemiological studies, it has been established that exposure to arsenic in drinking water over period of time causes acute illness. The studies are cross-section in nature and focus more on current exposure to the illness. The long term ( 5 to 10 years) exposure of arsenic in drinking water forms the basis of skin lesions (Keratosis, Melanosis), hyper pigmentation, and increased risks of lung, bladder and skin cancers, birth defects and peripheral nervous system. Arsenic related exposure hinders the social and economic cost of the affected person. There are very few studies available which has focused on both social and economic factors and tried to estimate the socio-economic cost involved to the household due to exposure of arsenic in drinking water. Arsenic in drinking water causes different types of cancer. National Academy of Sciences (NAS) 1999 correlated arsenic level in tap water and its total cancer risk (Table 4).

The arsenic problem also has a major effect on the socio-economic structure. The socio-economic problems can be mainly categorised into three classes as agricultural problem, health problem and other problems (Thakur et al. 2013). Excess presence of contaminated water leads to decrease in agricultural productivity, soil fertility, and also enters into the food chain which creates health problems. Brammer (2008) suggested that in India, Nepal and Bangladesh, arsenic contaminated water used for irrigation enters into the food chain. All these three problems lead to both social and 
economic problems. While skin lesions, bladder, cancer, and mortality are few of the resulting health problems; social ignorance, depression and suicidal tendency are among the few social problems.

Table 4: Arsenic in Drinking Water and Probability of Cancer

\begin{tabular}{|l|l|}
\hline $\begin{array}{l}\text { Arsenic Level in Tap Water (in parts per } \\
\text { billion, or ppb) }\end{array}$ & $\begin{array}{l}\text { Approximate Total Cancer Risk } \\
\text { (assuming 2 liters consumed per day) }\end{array}$ \\
\hline $0.5 \mathrm{ppb}$ & 1 in 10,000 \\
\hline $1 \mathrm{ppb}$ & 1 in 5,000 \\
\hline $3 \mathrm{ppb}$ & 1 in 1,667 \\
\hline $4 \mathrm{ppb}$ & 1 in 1,250 \\
\hline $5 \mathrm{ppb}$ & 1 in 1,000 \\
\hline $10 \mathrm{ppb}$ & 1 in 500 \\
\hline $20 \mathrm{ppb}$ & 1 in 250 \\
\hline $25 \mathrm{ppb}$ & 1 in 200 \\
\hline $50 \mathrm{ppb}$ & 1 in 100 \\
\hline Source: National Academy of Sciences (1999)
\end{tabular}

Arsenic related diseases are not spreadable disease. It is common myth among the households in rural areas that it is a spreadable disease. The possible solution is to initiate awareness programme by the government at the community or grassroots level. Arsenic groundwater contamination has severe economic effects on the people residing in the areas where the menace is found. There is dearth of studies on economic aspects of arsenic problems. The chronic effects of inorganic arsenic exposure via drinking water include skin lesions, such as hyper pigmentation and black foot disease, and respiratory symptoms, such as cough and bronchitis. Besides, there is sufficient evidence to link bladder and lung cancers with ingestion of inorganic arsenic (NRC, 2006).

Arsenic contaminated groundwater is used for agricultural irrigation resulting in excessive amount of available arsenic in the crops in that area. It has been reported that second to the ingestion of arsenic, after the direct consumption as drinking arsenic contaminated water, is through food chain, particularly use of contaminated rice followed by vegetables. This eventually indicates that the effects of this occurrence are far-reaching; the sooner we search sustainable solutions to resolve the problems, the lesser would be its future environmental, health, socio-economic and socio-cultural hazards (Ministry of Water Resources, 2010b). The fertilizers and pesticides used for agricultural purpose also cause arsenic contamination. Rice and vegetables have more effects on arsenic contaminated water. Brammer (2008) in his study suggested that 
arsenic-polluted water used for agriculture irrigation is a health hazard for the people eating food from the crops irrigated in the areas of India, Bangladesh and Nepal in recent times. Arsenic contaminated water used for irrigation can adversely affect the soil quality and hence reduce food production. Arsenic contaminated groundwater used for irrigation in the countries of south and south-east Asia is adding arsenic to soils and rice. This poses a serious risk to sustainable agricultural production and also the livelihoods and health of the affected population of those countries (Brammer, 2009). There are some possible mitigation strategies that can be adopted: the first is to provide the alternative irrigation sources and the second could be removal of contaminants from the soil by using the appropriate technology.

\subsection{Concluding remarks}

Bihar is one of the least developing states of India both in terms of per capita income and human development index. In the last few decades pollution of water level has increased due to excess exploitation of groundwater resources for irrigation and drinking purposes, rapid increase in industrialisation and urbanisation. Groundwater level is falling in many parts due to excess drawls leading to contamination problems with nitrate, fluoride, arsenic and other chemicals; this also contributes to contaminating potable water sources.

Accesses to safe and clean drinking water along with sanitation are basic human needs. They are fundamentally linked to the health and well-being of the people. The majority of the people are facing arsenic in their drinking water is from poor socioeconomic background. They are either not aware or if aware are forced to take drinking from same source due to lack of alternative sources of water. As Prime minister of India Dr. Manmohan Singh rightly said in his 2012 IWW speech that "With around 17\% of the world's population but only $4 \%$ of its usable freshwater, India has a scarcity of water. Rapid economic growth and urbanisation are widening the demand supply gap. Climate change could further aggravate the availability of water in the country as it threatens the water cycle. Our water bodies are getting increasingly polluted by untreated industrial effluents and sewage. Groundwater levels are falling in many parts due to excess drawls leading to contamination with fluoride, arsenic and other chemicals. The practice of open defecation, which regrettably is all too widespread, contributes to contaminating potable water sources". If we cannot be aware and take action then the condition of contamination will be worse than Bangladesh which will certainly affect sustainable health of the stakeholders in all aspects of life. 
56 | MANTHAN: Journal of Commerce and Management, Vol. 2, Issue 1

\section{References}

Baliga, Sandeep \& Maskin, Eric (2005). Mechanism Design for Environment. In KarlGoran Maller, and Jeffrey, R. Vincent (eds.), Handbook of Environmental Economics: Valuing Environmental Changes Vol. 1 ELSEVIER: North-Holland, pp. 305-324.

Brammer, Hugh. (2008). Threat of Arsenic to Agriculture in India, Bangladesh and Nepal. Economic and Political Weekly, November 22.

Brammer, Hugh. (2009). Mitigation of arsenic contamination in irrigated paddy soils in South and South-East Asia. Environment International 35: 856-863.

Canter, Kenneth. P. (1997). Drinking Water and Cancer. Cancer Causes and Control: The Harvard-Teikyo Special Issue, 8(3):292-308.

Chakraborti, A. K., \& Saha, K. C. (1987). Arsenic dermatoses from tube-well water in West Bengal. Indian Journal of Medical Research 85: 326-34.

Conrad, Jon M. (1999). Resource Economics. Cambridge University Press: New York.

Cvjetanovic, B. (1986). Health effects and impacts of water supply and sanitation. World Health Statistics Quarterly, 39(1): 105-117.

Dasgupta, Partha. (1993). An Enquiry into Well-being Destitution. Oxford University Press: New York.

Dasgupta, Partha. (2007). Economics: A Very Short Introduction. Oxford University Press: New York.

Dasgupta, Partha. (2010). The Concept of Natural Capital, lecture delivered at Royal Society on Inter Panel Academy Biodiversity Conference on January 12-13.

Egboka, B. C. E, Nwankwor, G. I., Orajaka, I. P. \& Ejiofor, A. O. (1989). Principles and problems of environmental pollution of groundwater resources with case examples from developing countries. Environmental Health Perspectives, 83: 39-68. 
Ghosh, A. K, Singh, S. K., Bose, N. \& Chaudhary, S. (2007). Arsenic contaminated aquifers: A study of the Ganga levee zones in Bihar, India. Symposium on Arsenic: The Geography of a global problem, Royal Geographical Society, London accessed on 12 December 2010 (Available online at: http://www.geo.cam.ac.uk/research/projects/arsenic/symposium/S3.5_A_Ghosh.pdf ).

Hotelling, H. (1931). The economics of exhaustible resources, Journal of Political Economy, 39(2): 137-75.

Jain, C. K., \& Ali, I. (2000). Arsenic: occurrence, toxicity and speciation techniques. Water Resources, 34(17): 4304- 4312.

Jain, J. K. (1977). India: Underground water resources and discussion, Philosophical Transactions of the Royal Society of London, Series B, Biological Sciences, 278 (962): 507-524.

Khan, M. Z. Hossain. (2007): Managing the Disaster in Water Supply: Risk Measurement, Costs of Illness and Policy Choices for Bangladesh, SANDEE Working Paper No. 27-07 Kathmandu, Nepal.

Khan, M. Z Hossain and A K E Haque (2011): Red wells, green wells and the costs of arsenic contamination in Bangladesh. In Haque, Murty and Shyamsundar (Eds.) Environmental Valuation in South Asia, Cambridge University Press: New Delhi.

Kondo, H., Ishiguro, Y., Ohno, K., Nagase, M., Toba, M. \& Takagi, M. (1999): Naturally occurring arsenic in the groundwaters in the southern region of Fukuoka prefecture. Japanese Water Research, 33(8): 1967-1972.

Ministry of Environment and Forest, Government of India (2009): State of Environment Report 2009, New Delhi.

Ministry of Environment and Forest, Government of India (2010): Report to the People on Environment and Forests 2009-2010, New Delhi.

Ministry of Water Resources, Government of India. (2000). Annual report 1999-00, New Delhi. 
Ministry of Water Resources, Government of India. (2006). Dynamic groundwater resources of India, Central Ground Water Board, New Delhi.

Ministry of Water Resources, Government of India. (2007). Annual report 2006-07, New Delhi.

Ministry of Water Resources, Government of India. (2008). Annual report 2007-08, New Delhi.

Ministry of Water Resources, Government of India. (2010a). Groundwater quality in shallow aquifers of India, Central Groundwater Board, Faridabad India.

Ministry of Water Resources, Government of India. (2010b). Mitigation and Remedy of Groundwater Arsenic Menace in India: A Vision Document, National Institute of Hydrology, Roorkee and Central Ground Water Board, New Delhi, India.

Mukherjee, A. (2006). Arsenic contamination in groundwater: a global perspective with emphasis on the Asian scenario, International Centre for Diarrheal Research, Bangladesh.

National Research Council. (2003-2006). Fluoride in drinking water: A scientific review of EPA's Standards, New Zealand.

Pigou, A.C. (1920). Economics of Welfare, Macmillan and Company.

Rahman, M, Tondel, M., Chowdhury, I. A. \& Axelson, O. (1999). Relations between exposure to arsenic, skin lesions and glucosuria. Occupational and Environmental Medicine, 56(4): 277-281.

Ravenscroft, P., Burgess, W. G., Ahmed, K. M., Burren, M. \& Perrin, J. (2008). Arsenic in groundwater of the Bengal Basin Bangladesh: Distribution, field relations and hydrological setting. Hydrology Journal, 13: 727-51.

Ravenscroft, P., Brammer, H., \& Richards, K. (2009). Arsenic Pollution: A Global Synthesis. Vol. 94, John Willey-Blackwell: London. 
Roy, Joyshree. (2007). Estimating the economic benefits of arsenic removal in India: A case study from West Bengal, SANDEE Working Paper No. 21-07 Kathmandu, Nepal.

Roy, Joyshree. (2008). Economic benefits of arsenic removal from ground water- A case study from West Bengal, India, Science of the total Environment 397: 1-12.

Roy, Joyashree et al. (2004). An economic analysis of demand for water quality: A case study from Kolkata city, Economic and Political Weekly, 39(2): 186-192.

Saha, Dipankar. (2009). Arsenic groundwater contamination in parts of middle Ganga plain, Bihar. Current Science, 96(6): 1-3.

Sankar, U. (2000). Environmental Economics, Reader in Economics, Oxford University Press: Oxford India Paperback 4th impression.

Sankar, U. (2005). Environmental Externalities, Dissemination Paper-1, Madras school of Economics.

Saxena, V. K., Kumar, S. \& Singh, V. S. (2004): Occurrence, behaviour and speciation of arsenic in groundwater, Current Science 86(2) pp. 281-284.

Smedley, P. L., \& Kinniburgh, D. G. (2002). A review of the source, behaviour and distribution of arsenic in natural waters. Applied Geochemistry, 17(3): 517-568.

Sparks, Donald, L. (2005). Advances in Agronomy, Elsevier Academy.

Thakur, B.K., Gupta, V., Chattopadhyay, U. (2013). Arsenic Groundwater Contamination Related Socio-Economic Problems in India: Issues and Challenges. In Nautiyal, Rao, Kaechele, Raju, and Schaldach (Eds.) Knowledge Systems of Societies for Adaptation and Mitigation of Impacts of Climate Change, Environmental Science and Engineering. Springer-Verlag Berlin Heidelbergh. pp. 163-182.

United Nations. (2009). The Millennium Development Goals Report 2009.

United Nations. (2010): The Millennium Development Goals Report 2010. 
60 | MANTHAN: Journal of Commerce and Management, Vol. 2, Issue 1

UN Millennium Project Task Force on Environmental Sustainability. (2005). Environment and Human Well-being: A Practical Strategy, EARTHSCAN London.

World Health Organization. (2001). Bulletin of the WHO, 78(9): 1096-97.

World Health Organization. (2010). Water for health: WHO Guidelines for Drinkingwater Quality, 1: 1-6. 